\title{
Comparative Response of Three Crop Species to Liming Several Soils of the Southeastern United States and of Puerto Rico ${ }^{1,2}$
}

\author{
Robert W. Pearson, Raúl Pérez-Escolar, F. Abruña, Zane F. Lund, \\ and E. J. Brenes ${ }^{3}$
}

\section{ABSTRACT}

Yield response of three plant species to liming was determined in pot tests using soils typical of the humid upland region of Puerto Rico and of the southeastern United States. Three general response patterns were observed, but they were not clearly related to either crop species or soil category: 1) Increasing yield with increasing soil $\mathrm{pH}$ to a maximum between 5 and 6 , followed by little or no change at higher $\mathrm{pH}$ values; 2 ) no clear response; and 3) increasing yield with increasing $\mathrm{pH}$ to a maximum between 5 and 6 , followed by a decrease at higher $\mathrm{pH}$ values.

These results support the concept that satisfactory plant growth can be made on acid soils of tropical regions at somewhat lower $\mathrm{pH}$ levels than on soils of temperate regions. They also suggest that liming experience gained in temperate zones could be used with caution for acid soils of tropical regions.

\section{INTRODUCTION}

Judicious applications of lime are necessary for effective agricultural use of highly-weathered acid soils of both temperate and tropical regions. In temperate regions liming is probably as old as organized agriculture, but in the tropics it is being adopted much more slowly. There are several reasons for this. Availability and cost of lime are frequently limiting factors. Furthermore, liming recommendations in the tropics have often been strongly influenced by, if not derived from, results reported from less weathered and leached soils in temperate climates.

A number of workers $(19,25,29)$ have pointed out the dangers of assuming similar responses to liming of soils of temperate and tropical regions. Yet, soil characteristics in humid-temperate and humid-tropical regions overlap extensively. Among all the soil orders, only Oxisols are restricted to the tropics (32). Useful extrapolation of liming experience to tropical soils should, therefore, be possible as better insight is

${ }^{1}$ Manuscript submitted to Editorial Board July 21, 1975.

${ }^{2}$ This study was supported in part by the U.S. Agency for International Development under research contract csd ta-c-1104 with Cornell University entitled: Soil Fertility of the Humid Tropics.

${ }^{3}$ Consultant, University of Puerto Rico and Cornell University; Soil Scientist, Agricultural Experiment Station, University of Puerto Rico; Soil Scientist, ARS, USDA, Río Piedras, P.R.; Soil Scientist, ARS, USDA, Auburn, Ala.; and Associate Soil Scientist, Agricultural Experiment Station University of Puerto Rico, Río Piedras, P.R., respectively. 
gained into the specific underlying causes of acid-soil infertility and how they differ among broad groups of soils.

The purpose of the series of experiments presented in this report was to compare the response to lime of several plant genotypes common to the regions in question when grown on Oxisols and Ultisols typical of the upland soils of the southeastern United States where extensive liming research results are available, and of Puerto Rico, where 9 of the 10 soil orders (Soil Taxonomy) are found. A further objective was to attempt to identify the specific causes of any reduced plant growth associated with either a deficiency or excess of applied lime.

Several reviews provide up-to-date summaries of available information on liming of highly weathered soils and rationalization of observed effects $(3,9,14,17,23)$. Due to the wide differences in response to lime among soils of any climatic region, many exceptions to generalizations regarding response of tropical and temperate region soils to liming should be expected. However, several points of difference appear to be fairly consistent. For example, crop yields are usually better in the tropics at lower soil $\mathrm{pH}$ levels than would be expected with similar crop species in temperate regions $(7,28)$. It is not known to what extent crop adaptation may contribute to this behavior. Several crops adapted to the tropics, such as tea, coffee, and peanuts, are highly tolerant to $\mathrm{Al}$ toxicity, but some varieties of these crops $(12,13,28)$ differ widely in tolerance. Furthermore, maximum response to lime applications has been observed to occur at lower rates in the tropics than in other areas (28), suggesting that supplying $\mathrm{Ca}$ and $\mathrm{Mg}$ as nutrients may often be involved in response by the former soils. Also, the more highly weathered and leached soils of the humid tropics repeatedly have been reported to be susceptible to overliming, whereas such effects have not been of any consequence in temperate region soils $(23,25)$.

Thus, previous work suggests that in dealing with acid soils of the humid tropics, acidity may be less injurious and less lime is probably required for adequate correction than in soils of the temperate regions.

\section{EXPERIMENTAL METHODS}

\section{GENERAL}

The study was conceived as a means of identifying any outstanding differences between typical upland soils developed under humid-temperate and humid-tropical conditions as shown by response of identical plant genotypes to variations in soil $\mathrm{pH}$. Location effects were minimized by the use of pot experiments (1-gal size) in a glass house in Río Piedras, Puerto Rico, and in a growth chamber in Auburn, Alabama. The soils from Puerto Rico were used in the Rio Piedras experiment and those from the southeastern United States were used in the Auburn 
experiment. No attempt was made to maintain identical temperatures in the two locations, but they were similar, ranging around $30^{\circ} \mathrm{C}$ maximum during the day. Test plants were planted from the same lot of seed in all experiments, using an acid-sensitive, an intermediate-sensitive, and an acid-tolerant species. The plants were grown for 3 to 4 weeks before harvesting and determination of total dry weight of the aboveground material.

In carrying out these experiments, two problems were a constant source of concern. The first was maintaining an adequate supply of water without having at times an excess in the fine-textured soils or leaching the coarse-textured ones. This was finally settled by the use of large, woven fiber glass wicks placed in firm contact with the soil through the center of the pots and dipping in a reservoir of water beneath. This procedure gave much more uniform water levels in the soils than could be attained by additions to the pots as need appeared by either observation or weighing. The second problem was the tendency of the soils to shift in $\mathrm{pH}$ with time due to fertilizer reactions and accumulation of salts. In the poorly buffered soils, especially, the problem was serious and could not be solved satisfactorily. Soil $\mathrm{pH}$ could be determined in each pot only at the beginning of each experiment.

\section{ANALYTICAL METHODS}

Soil $\mathrm{pH}$ was determined with the glass electrode using 1:2.5 soil-water suspension. Soil solutions were displaced from soil samples taken at time of potting and after equilibration for $24 \mathrm{hr}$ at the $1 / \mathrm{s}-\mathrm{atm} \mathrm{H}_{2} \mathrm{O}$ content. The solutions were analyzed for $\mathrm{Ca}, \mathrm{Mg}, \mathrm{K}, \mathrm{Al}$, and $\mathrm{Mn}$, using the following procedures: EDTA titration for $\mathrm{Ca}$ and $\mathrm{Mg}$, flame photometry for K, Eriochrome Cyanine R method (15) for Al; and colorimetric determinations of $\mathrm{Mn}$ following oxidation to $\mathrm{KMnO}_{4}$. Exchangeable cations were determined using the same procedures after ammonium acetate extraction of the basic cations and $\mathrm{KCl}$ extraction of $\mathrm{Al}$.

Plant material from selected treatments of each crop at harvest was spectrographically analyzed for both major and micronutrient contents by the Soil Testing and Plant Analysis Laboratory at Athens, Georgia. Plants grown under highly acid, intermediate, and "overlimed" conditions were included in the samples analyzed.

\section{SOILS}

Six different acid soils, three from the humid region of Puerto Rico and three from the southeastern United States, were selected to provide a wide range in degree of weathering and difference in response to lime applications $(1,4,23)$. The soils, listed in table 1 , were four Ultisols and two Oxisols. All were strongly acid, and ranged in texture from loamy 
sand to clay. Bulk samples of each soil were taken from unlimed plots in field experiments. These soils had all been used for row crop production for many years, during which time residually acid fertilizers had been used. Even so, the $\mathrm{pH}$ range, between 4.3 and 4.6 , is probably not unusually low for unlimed soils of these series $(22,27)$.

\section{TEST PLANTS}

The test plant varieties selected were Sudangrass (Sorghum sudanensis, [ Piper] Stapf, corn (Zea mays L. var. Funk SX 4949), and soybean (Glycine max. [L] Merr. var. Hardee). All were chosen in consultation with research workers familiar with general performance of the crops in both temperate and tropical climates. Sudangrass is

TABLE 1.-Description of soils included in liming experiments

\begin{tabular}{|c|c|c|c|}
\hline Soil series & Classification & Location & $\begin{array}{c}\text { Initial } \\
\mathbf{p H}\end{array}$ \\
\hline Bladen clay loam & $\begin{array}{l}\text { Typic Albaquults } \\
\text { clayey, mixed, } \\
\text { thermic }\end{array}$ & Fleming, Ga. & 4.6 \\
\hline Norfolk loamy sand & $\begin{array}{l}\text { Typic Paleudults } \\
\text { fine-loamy, siliceous, } \\
\text { thermic }\end{array}$ & Headland, Ala. & 4.4 \\
\hline Lucedale sandy loam & Rhodic Paleudults & Thorsby, Ala. & 4.4 \\
\hline Catalina clay & $\begin{array}{l}\text { Tropeptic Haplorthox } \\
\text { clayey, oxidic, } \\
\text { isohyperthermic }\end{array}$ & Barranquitas, P. R. & 4.3 \\
\hline Humatas clay & $\begin{array}{l}\text { Typic Tropohumults } \\
\text { clayey, kaolinitic, } \\
\text { isohyperthermic }\end{array}$ & Orocovis, P. R. & 3.9 \\
\hline Coto clay & $\begin{array}{l}\text { Tropeptic Haplorthox } \\
\text { clayey, kaolinitic, } \\
\text { isohyperthermic }\end{array}$ & Isabela, P. R. & 4.3 \\
\hline
\end{tabular}

widely recognized as a very acid-sensitive crop, having an especially low tolerance for $\mathrm{Al}$ (26). The soybean plant, on the other hand, has relatively high tolerance of acidity. Although it may be somewhat more Mnsensitive than many species (21), it is relatively tolerant of solution $\mathrm{Al}$ (26). Corn, in the authors' experience, has been intermediate in its tolerance of soil acidity $(1,3)$. Of course, wide variations in tolerance are expected among varieties of any crop, as has been demonstrated for both temperate and tropical conditions $(5,28)$.

\section{LIME AND FERTILIZER TREATMENTS}

Bulk lots of each soil $(25 \mathrm{~kg}$ ) were treated with finely-ground (100mesh) dolomitic limestone at a number of rates to provide a final soil $\mathrm{pH}$ ranging from that of the unlimed sample up to at least $\mathrm{pH}$ 7.0. These 
bulk samples were equilibrated at the $1 / 3$-atm $\mathrm{H}_{2} \mathrm{O}$ percentage for about 1 week before potting. The soils were fertilized with $\mathrm{P}$ and $\mathrm{K}$ according to soil test, $\mathrm{N}$ was added at the rate of $120 \mathrm{p} / \mathrm{m}$ as $\mathrm{NH}_{4} \mathrm{NO}_{3}$ in solution when the soil moisture level was adjusted just prior to potting and planting. No micronutrients were included in the fertilization.

\section{RESULTS AND DISCUSSION}

\section{SOIL PROPERTIES}

Exchangeable cations in the unlimed soils and at an intermediate and a relatively high $\mathrm{pH}$ are shown in table 2 . Cation exchange capacity, as

TABLE 2. -Some soil chemical properties at several $p H$ levels resulting from differential lime applications

\begin{tabular}{|c|c|c|c|c|c|c|}
\hline \multirow{2}{*}{ Soil } & \multirow{2}{*}{ Soil pH } & \multicolumn{4}{|c|}{ Exchangeable cations, meq $/ 100 \mathrm{~g}$} & \multirow{2}{*}{$\Sigma$ cations } \\
\hline & & $\mathrm{Ca}$ & $\mathrm{Mg}$ & $\mathrm{K}$ & $\mathrm{Al}$ & \\
\hline Norfolk sandy & 4.4 & 0.26 & 0.13 & 0.39 & 0.33 & 1.1 \\
\hline \multirow[t]{2}{*}{ loam } & 4.8 & .34 & .15 & .38 & .23 & 1.1 \\
\hline & 6.4 & .80 & .50 & .38 & .0 & 1.7 \\
\hline Lucedale & 4.4 & .76 & .63 & 1.10 & 1.23 & 2.7 \\
\hline \multirow[t]{2}{*}{ sandy loam } & 4.8 & 1.70 & .83 & .07 & .87 & 3.5 \\
\hline & 5.8 & 2.28 & .98 & .06 & .0 & 3.3 \\
\hline Bladen clay & 4.6 & 3.30 & 4.90 & .11 & 5.66 & 14.0 \\
\hline \multirow[t]{2}{*}{ loam } & 5.2 & 6.20 & 11.20 & .12 & 1.12 & 18.6 \\
\hline & 6.4 & 10.00 & 6.00 & .18 & .0 & 16.2 \\
\hline \multirow[t]{3}{*}{ Humatas clay } & 3.9 & 3.49 & .62 & $\mathrm{ND}^{1}$ & 5.30 & 9.41 \\
\hline & 4.2 & 4.70 & 1.21 & ND & 3.48 & 9.39 \\
\hline & 6.0 & 7.70 & 2.25 & ND & .0 & 9.95 \\
\hline \multirow[t]{3}{*}{ Catalina clay } & 4.3 & 5.52 & 4.14 & ND & 1.95 & 11.61 \\
\hline & 4.4 & 4.73 & 3.97 & ND & 1.72 & 10.42 \\
\hline & 5.7 & 5.80 & 3.07 & ND & .0 & 8.87 \\
\hline \multirow[t]{3}{*}{ Coto clay } & 4.3 & 1.87 & .18 & ND & 1.53 & 3.58 \\
\hline & 4.5 & 2.58 & .31 & ND & .90 & 3.79 \\
\hline & 6.7 & 3.64 & 1.51 & ND & .0 & 5.15 \\
\hline
\end{tabular}

' Exchangeable $\mathrm{K}$ was not determined on these soils, but soil tests results indicated no abnormal deviations from commonly occuring levels which range around $0.1 \mathrm{meq} / 100 \mathrm{~g}$.

indicated by $\Sigma$ cations, ranged from only about $1 \mathrm{meq} / 100 \mathrm{~g}$ in the Norfolk to around 18 in the Bladen. This was not quite as wide as the range among the Puerto Rican soils (about 4 to $11 \mathrm{meq} / 100 \mathrm{~g}$ ). Exchangeable $\mathrm{Al}$ was relatively high in all unlimed soils, amounting to around $50 \%$ of the exchangeable cations in all but the Catalina soil. In this soil it tended to conform to levels expected for an Oxisol. None of the unlimed soils had a ratio $\Sigma$ cations:Ca below those previously reported as growth limiting (11), nor did $\mathrm{Mg}$ approach levels considered phytotoxic.

The concentration of various cations in the displaced soil solution at 
several soil $\mathrm{pH}$ levels, and the calculated molar activity of the potentially toxic $\mathrm{Al}$ and $\mathrm{Mn}$ ions are listed in tables 3 and 4 . Here again, the $\mathrm{Ca}$ level should have been adequate in all cases, and $\mathrm{Mg}$ was usually not excessive. However, $\mathrm{Al}$ was present at toxic levels in all the soil solutions at $\mathrm{pH}$ levels below about 5.0, and $\mathrm{Al}$ activity was very high at the lowest $\mathrm{pH}$ values. The relationship between soil solution $\mathrm{pH}$ and chemical activity of the soluble $\mathrm{Al}$ is shown in figure 1. Any increase in chemical activity of $\mathrm{Al}$ in the soil solution above zero reportedly decreases cotton root extension (2). Figure 1 also shows that when all six

TABLE 3.-Soil solution cation composition-soils from southeastern United States

\begin{tabular}{|c|c|c|c|c|c|c|c|c|}
\hline \multirow{2}{*}{ Soil } & \multirow{2}{*}{$\begin{array}{c}\text { Solu- } \\
\text { tion } \\
\text { pH }\end{array}$} & \multicolumn{5}{|c|}{ Soil solution composition } & \multirow{2}{*}{ Al activ- } & \multirow{2}{*}{$\begin{array}{c}\text { Mn ac- } \\
\text { tivity }\end{array}$} \\
\hline & & $\mathrm{Ca}$ & $\mathrm{Mg}$ & $\mathbf{K}$ & $\mathrm{Al}$ & $\mathrm{Mn}$ & & \\
\hline & & & & $m M$ & & & $\mu \bar{M}$ & $\mu \bar{M}$ \\
\hline \multirow[t]{6}{*}{ Norfolk } & 4.0 & 5.1 & 2.1 & 15.1 & 0.95 & 0.7 & 134.1 & 349 \\
\hline & 4.5 & 6.6 & 6.2 & 13.6 & .21 & .4 & 26.2 & 189 \\
\hline & 4.7 & 6.8 & 7.2 & 13.4 & .12 & .6 & 13.9 & 279 \\
\hline & 4.8 & 7.1 & 9.6 & 12.1 & .04 & .3 & 3.8 & 136 \\
\hline & 6.7 & 8.3 & 20.1 & 8.3 & - & $\operatorname{tr}$ & - & - \\
\hline & 7.1 & 11.6 & 28.2 & 8.6 & - & tr & - & - \\
\hline \multirow{6}{*}{ Lucedale } & 3.9 & 9.3 & 4.2 & 5.6 & 1,33 & .5 & 184.5 & 234 \\
\hline & 4.0 & 11.4 & 5.5 & 5.4 & 1.02 & .4 & 132.5 & 181 \\
\hline & 4.1 & 16.3 & 4.9 & 5.5 & .75 & .2 & 90.2 & 87 \\
\hline & 4.2 & 19.4 & 9.5 & 5.3 & .36 & .1 & 39.2 & 41 \\
\hline & 4.8 & 27.3 & 21.3 & 2.5 & .09 & .1 & 7.0 & 36 \\
\hline & 6.7 & 24.4 & 28.2 & 1.2 & - & tr & - & - \\
\hline \multirow[t]{6}{*}{ Bladen } & 4.2 & 6.1 & 3.3 & .4 & .64 & .1 & 177.1 & 53 \\
\hline & 5.0 & 6.6 & 5.6 & .3 & .27 & .1 & 25.6 & 51 \\
\hline & 5.7 & 12.1 & 12.3 & .3 & .14 & $\operatorname{tr}$ & 16.4 & - \\
\hline & 6.1 & 10.1 & 10.0 & .3 & - & $\operatorname{tr}$ & - & - \\
\hline & 6.5 & 13.2 & 12.2 & .4 & - & $\operatorname{tr}$ & - & - \\
\hline & 7.5 & 21.4 & 18.5 & .4 & - & tr & - & - \\
\hline
\end{tabular}

soil solution $\mathrm{Al}$ contents were expressed in terms of chemical activity, they had essentially the same pattern as soil solution $\mathrm{pH}$ was varied from 3.5 to 7.0. This observation agrees with those of other workers (7) that "critical" soil pH for plant growth is often lower in Puerto Rican soils than in those of the southeastern U.S. Chemical activity of soilsolution $\mathrm{Al}$ includes factors not represented adequately in a simple soil $\mathrm{pH}$ measurement. Figure 1 emphasizes the close relationship between $\mathrm{pH}$ of the true soil solution and the chemical activity of its $\mathrm{Al}$ content.

Figure 2 shows that there is a general relationship between soil 
suspension and displaced soil-solution $\mathrm{pH}$, with the latter around 0.5 unit lower than the former. The soils did not seem to differ consistently in this relationship.

Tables 3 and 4 also show the concentration and chemical activity of $\mathrm{Mn}$ in the displaced soil solution at varying $\mathrm{pH}$ levels. Generally, soluble $\mathrm{Mn}$ level decreased as $\mathrm{pH}$ increased, reaching extremely low values near $\mathrm{pH}$ 7. However, Bladen soil solutions contained little more than traces of $\mathrm{Mn}$ even at very low $\mathrm{pH}$, whereas Catalina solutions had extremely high concentrations when $\mathrm{pH}$ was below about 5 . Manganese solubility in soils is a highly labile property, making it difficult to

TABLe 4.-Soil solution cation composition-soils from Puerto Rico

\begin{tabular}{|c|c|c|c|c|c|c|c|c|}
\hline \multirow{2}{*}{ Soil } & \multirow{2}{*}{$\begin{array}{c}\text { Solu- } \\
\text { tion } \\
\mathrm{pH}\end{array}$} & \multicolumn{5}{|c|}{ Soil solution composition } & \multirow{2}{*}{$\begin{array}{c}\text { Al activ- } \\
\text { ity }\end{array}$} & \multirow{2}{*}{$\begin{array}{c}\text { Mn ac- } \\
\text { tivity }\end{array}$} \\
\hline & & $\mathrm{Ca}$ & $\mathrm{Mg}$ & $\mathbf{K}$ & $\mathrm{Al}$ & $\mathrm{Mn}$ & & \\
\hline & & & & $m M$ & & & $\mu \bar{M}$ & $\mu M$ \\
\hline \multirow[t]{8}{*}{ Humatas clay } & 3.5 & 13.1 & 3.2 & 0.8 & 2.3 & 0.6 & 471 & 287 \\
\hline & 3.6 & 13.9 & 4.8 & 1.0 & 2.6 & .8 & 500 & 339 \\
\hline & 3.7 & 11.2 & 3.7 & .3 & 1.4 & .6 & 331 & 309 \\
\hline & 3.8 & 8.3 & 1.9 & .3 & .7 & .5 & 179 & 229 \\
\hline & 4.1 & 13.6 & 4.7 & .2 & .4 & .6 & 85 & 289 \\
\hline & 4.7 & 7.0 & 1.0 & 1.3 & .1 & .4 & 20 & 200 \\
\hline & 5.0 & 12.2 & 2.2 & 1.2 & 0 & .3 & 0 & 125 \\
\hline & 6.5 & 2.6 & 1.7 & .1 & 0 & 0 & 0 & 0 \\
\hline \multirow[t]{6}{*}{ Coto clay } & 4.1 & 8.4 & 1.2 & .5 & .8 & 1.9 & 196 & 901 \\
\hline & 4.2 & 5.4 & .5 & .1 & .3 & 1.3 & 101 & 717 \\
\hline & 4.3 & 3.2 & - & .3 & .3 & .8 & 91 & 702 \\
\hline & 4.5 & 5.1 & .6 & .1 & .2 & 1.0 & 56 & 578 \\
\hline & 5.8 & 1.8 & .9 & .1 & 0 & 0 & 0 & 0 \\
\hline & 6.7 & 3.2 & 2.2 & .1 & 0 & 0 & 0 & 0 \\
\hline \multirow[t]{6}{*}{ Catalina clay } & 4.1 & 18.8 & 1.8 & .8 & .5 & 20.8 & 74 & 8355 \\
\hline & 4.2 & 15.2 & 2.7 & .5 & .4 & 19.8 & 59 & 7441 \\
\hline & 4.3 & 16.5 & 4.6 & .5 & .3 & 20.6 & 46 & 7526 \\
\hline & 4.4 & 26.0 & 2.3 & .5 & .2 & 22.3 & 24 & 7777 \\
\hline & 5.0 & 8.4 & 2.8 & .1 & 0 & .3 & 0 & 148 \\
\hline & 6.4 & 2.2 & 1.0 & .1 & 0 & 0 & 0 & 0 \\
\hline
\end{tabular}

establish relationships to plant growth that may occur over a period of several weeks, as illustrated by the results in figure 3 . At the same $\mathrm{pH}$ level, soil solution $\mathrm{Mn}$ activity in the Coto clay decreased sharply between potting and a sampling after the third test crop had been harvested. Such changes are known to be influenced by drying, wetting, temperature changes, and other factors.

The plant composition results listed in tables 5 through 7 show that Ca level did not drop below $0.2 \%$ in any of the plant materials, regardless of soil type or liming treatment. This level should have been 
adequate for normal plant growth (30). This conclusion is also supported by the soil-solution cation composition results (tables 3 and 4).

Similarly, P content of the plant materials appeared normal, usually around $0.2 \%$. This agrees with previously reported effects of $\mathrm{Al}$ on $\mathrm{P}$ uptake and translocation, which varied from increases (24) through no effect $(20,8)$ to decreases $(12,13)$, depending on plant species and environmental factors.

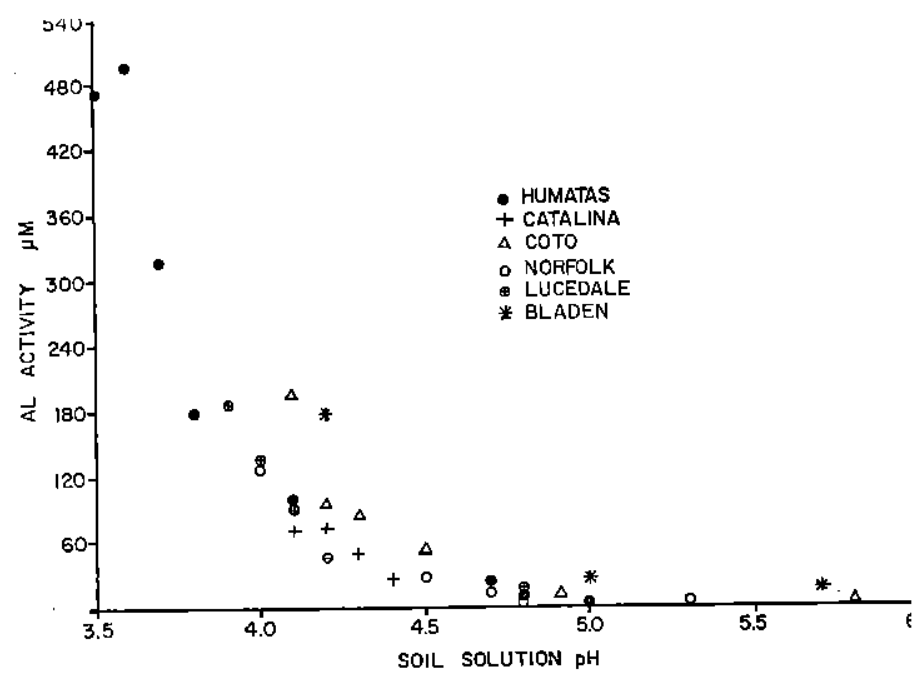

FIG. 1.-Relationship of Al activity to soil solution $\mathrm{pH}$ among several soils of tropical and temperate climatic regions.

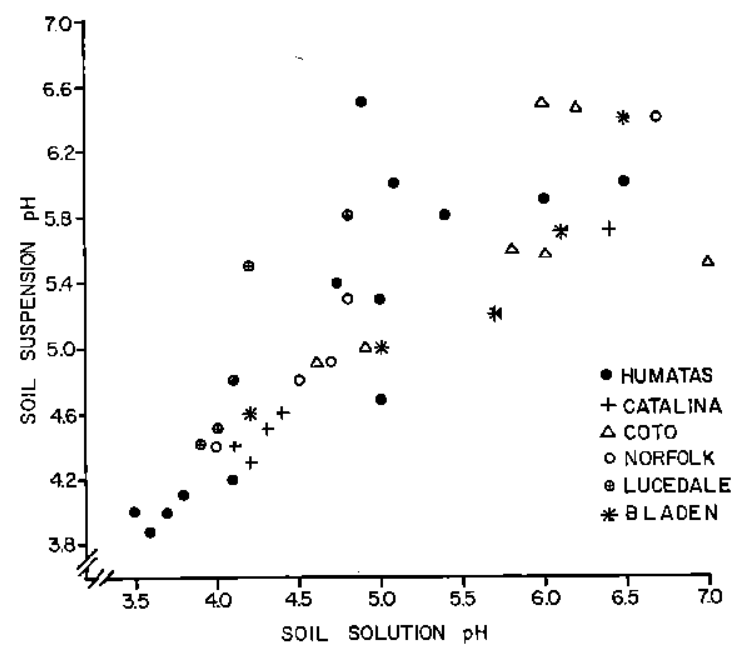

FIG. 2.-Relationship of soil suspension pH to that of the displaced soil solution. 
Magnesium content of some plant materials varied much more with liming than did $\mathrm{Ca}$ content. For example, for all soil types sudangrass had much higher $\mathrm{Mg}$ contents at high $\mathrm{pH}$ levels than in the unlimed or lightly limed treatments, yet $\mathrm{Ca}$ content varied little with treatment (tables 5, 6, and 7). Jackson (14) has emphasized the complex relationships involved in $\mathrm{Mg}$ uptake and translocation by plants, including interactions of $\mathrm{Mg}$ with $\mathrm{Al}, \mathrm{Mn}$, and $\mathrm{P}$. The present data do not support any clear conclusions concerning relationships between liming and $\mathrm{Mg}$ uptake or plant yield.

\section{YIELD RESPONSE}

Yield responses of the three crop species to liming are shown in figures 4 through 9 . Often the same crop was grown several times and

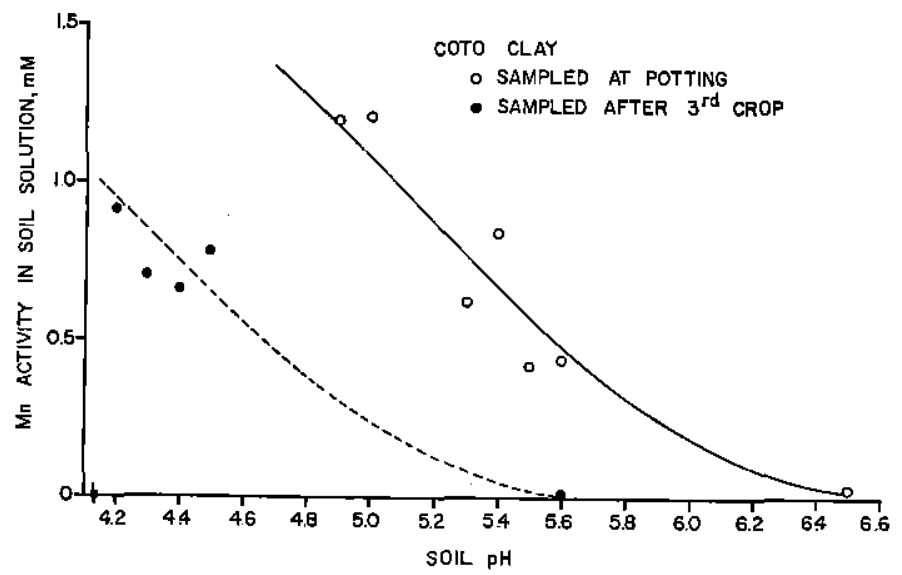

FIG. 3.-Changes in soil solution $\mathrm{Mn}$ level with cropping over a wide soil $\mathrm{pH}$ range.

the data were combined. Field experiment results were available from the Bladen clay loam site and are shown on the same graphs to compare responses (figure 4). Soybeans and corn grown on the Bladen soil responded similarly to liming in both field and pot tests.

Three general response patterns were observed, but they are not clearly related to either crop species or soil. These are, in the order of frequency of occurrence: 1) Increasing yield with increasing soil $\mathrm{pH}$ to a maximum between $\mathrm{pH} 5$ and 6 , followed by little or no change at higher $\mathrm{pH}$ levels; 2) no yield response to increasing $\mathrm{pH}$; and 3) increasing yield with increasing $\mathrm{pH}$ to a maximum between $\mathrm{pH} 5$ and 6 , followed by a tendency to decrease at higher $\mathrm{pH}$ values.

\section{Bladen Clay}

All three crops responded to liming the Bladen soil, and they appeared to differ little in the soil $\mathrm{pH}$ required for maximum yield (figure 4). None 
TABLE 5. - Composition of sudangrass with respect to several essential elements and soil pH level ${ }^{1}$

\begin{tabular}{|c|c|c|c|c|c|c|}
\hline Soil reaction & $\mathrm{P}$ & $\mathrm{Ca}$ & $\overline{\mathrm{Mg}}$ & $\overline{\mathrm{Mn}}$ & B & $\mathrm{Zn}$ \\
\hline$p H$ & $\%$ & $\%$ & $\%$ & $P / m$ & $P / m$ & $P / m$ \\
\hline \multicolumn{7}{|c|}{ Norfolk sandy loam } \\
\hline 4.1 & 0.4 & 0.2 & 0.2 & 796 & 9 & $>300$ \\
\hline 4.7 & .6 & - & - & 829 & 15 & $>300$ \\
\hline 6.5 & .4 & .3 & 1.3 & 108 & 8 & 91 \\
\hline 7.5 & .3 & .4 & 1.3 & 64 & 4 & 47 \\
\hline \multicolumn{7}{|c|}{ Lucedale sandy loam } \\
\hline 4.0 & .2 & 1.2 & .8 & 401 & 12 & $>300$ \\
\hline 4.6 & .2 & 1.1 & 1.8 & 128 & 5 & $>300$ \\
\hline 6.4 & - & .7 & 1.0 & 65 & 6 & 167 \\
\hline \multicolumn{7}{|c|}{ Bladen clay } \\
\hline 4.5 & .3 & .6 & .5 & 89 & 18 & 211 \\
\hline 4.9 & .2 & .3 & .4 & 57 & 18 & 91 \\
\hline 5.5 & .2 & .4 & .6 & 37 & 9 & 44 \\
\hline 7.2 & .5 & .8 & 1.1 & 3 & 8 & 34 \\
\hline \multicolumn{7}{|c|}{ Catalina clay } \\
\hline 4.7 & .2 & .3 & .1 & $>898$ & 10 & 41 \\
\hline 4.9 & .2 & .4 & .3 & $>898$ & 8 & 50 \\
\hline 5.3 & .2 & .4 & 1.0 & 146 & 4 & 34 \\
\hline 6.0 & .2 & .5 & 1.6 & 113 & 2 & 21 \\
\hline \multicolumn{7}{|c|}{ Humatas clay } \\
\hline 4.3 & .2 & 1.3 & .3 & 722 & 21 & 50 \\
\hline 4.7 & .2 & .5 & .6 & 368 & 8 & 45 \\
\hline 5.6 & .2 & .5 & .9 & 53 & 6 & 39 \\
\hline 6.7 & .2 & .6 & 1.6 & 22 & 2 & 36 \\
\hline \multicolumn{7}{|c|}{ Coto clay } \\
\hline 4.5 & .2 & .6 & .2 & $>898$ & 15 & 43 \\
\hline 5.0 & .1 & .7 & .3 & $>898$ & 16 & 48 \\
\hline 5.4 & .2 & .6 & .5 & 598 & 10 & 63 \\
\hline 6.0 & .2 & .5 & .7 & 327 & 9 & 59 \\
\hline
\end{tabular}

${ }^{1}$ All plant analyses were performed spectrographically in a routine plant analysis laboratory which did not vary dilution of solutions analyzed to fit individual sample concentrations of $\mathrm{Mn}$ or $\mathrm{Zn}$ except by special request on samples when resubmitted. For this reason, when $\mathrm{Mn}$ or $\mathrm{Zn}$ are reported as $>898$ or $>300$, respectively, readings were off scale at standard routine dilution, and samples of the particular plant tissue were no longer available for reruns.

responded to an increase in $\mathrm{pH}$ above about 5.5. This was a direct reflection of soil solution $\mathrm{Al}$ activity, which reached a low level at $\mathrm{pH}$ 5.7. Also, soluble $\mathrm{Mn}$ was very low at all $\mathrm{pH}$ values (table 3 ).

Sudangrass yield decreased as soil $\mathrm{pH}$ increased to values above about 6. This detrimental effect of high $\mathrm{pH}$ seemed to be due to Mn deficiency, based on both plant symptoms and composition. At $\mathrm{pH} 7.0$ the plant material contained only $3 \mathrm{p} / \mathrm{m} \mathrm{Mn}$ as compared with about $60 \mathrm{p} / \mathrm{m}$ or more at $\mathrm{pH}$ levels below 5.5. However, $\mathrm{Mn}$ content of both soybean and 
corn plants was this low at high soil $\mathrm{pH}$ values (tables 6 and 7), yet there were no visible symptoms of $\mathrm{Mn}$ deficiency in either crop, nor was there indication of yield depression of soybeans. Corn yield, nevertheless, seemed to decrease somewhat as soil $\mathrm{pH}$ increased above 7 .

\section{Norfolk Sandy Loam}

The three crops showed no clear difference in response patterns on the Norfolk soil (figure 5). Yield of all three crops increased as soil $\mathrm{pH}$ increased to between 5.5 and 6.5.

The response pattern corresponded very well with that of Al activity in the soil solution, which was probably the chief factor governing plant behavior with respect to acidity. Both corn and soybeans showed clear yield increases as soil $\mathrm{pH}$ was raised from 5.0 to 5.5, and sudangrass yield continued to increase up to at least $\mathrm{pH} 6.5$.

TARLE 6. -Composition of corn tissue with respect to several elements and soil pH level

\begin{tabular}{|c|c|c|c|c|c|c|}
\hline Soil reaction & $P$ & $\overline{\mathrm{Ca}}$ & $\mathrm{Mg}$ & Mn & $B$ & $\mathrm{Zn}_{\mathbf{n}}$ \\
\hline$p H$ & $\%$ & $\%$ & $\%$ & $P / m$ & $P / m$ & $P / m$ \\
\hline \multicolumn{7}{|c|}{ Norfolk sandy loam } \\
\hline 4.3 & 0.8 & 0.2 & 0.1 & $>898$ & 63 & $>300$ \\
\hline 4.6 & 4 & .6 & .5 & $>898$ & 40 & $>300$ \\
\hline 5.6 & .4 & .5 & .6 & 714 & 40 & $>300$ \\
\hline 7.6 & .4 & .5 & 1.3 & 119 & 15 & 79 \\
\hline \multicolumn{7}{|c|}{ Lucedale sandy loam } \\
\hline 4.3 & .2 & .7 & .1 & $>898$ & 50 & $>300$ \\
\hline 5.0 & .4 & .8 & 1.7 & 442 & 18 & 287 \\
\hline 5.5 & .3 & .7 & 2.0 & 96 & 18 & 66 \\
\hline \multicolumn{7}{|c|}{ Bladen clay } \\
\hline 4.3 & .2 & .8 & 1.2 & 221 & 48 & 290 \\
\hline 4.7 & .1 & .5 & 1.0 & 119 & 28 & 139 \\
\hline 5.5 & .3 & .5 & 1.8 & 3 & 19 & 240 \\
\hline 7.8 & .2 & 1.0 & 2.0 & 1 & 6 & 70 \\
\hline \multicolumn{7}{|c|}{ Catalina clay } \\
\hline 4.7 & .2 & .5 & .1 & $>4490$ & 42 & 38 \\
\hline 5.1 & .2 & .5 & .2 & $>4490$ & 48 & 43 \\
\hline 5.5 & .1 & .6 & 1.4 & 281 & 34 & 40 \\
\hline 6.0 & .1 & .6 & 1.0 & 218 & 28 & 26 \\
\hline \multicolumn{7}{|c|}{ Humatas clay } \\
\hline 4.0 & .2 & .5 & .2 & 1140 & 78 & 49 \\
\hline 4.8 & .2 & .7 & .3 & 1320 & 73 & 51 \\
\hline 5.4 & .2 & .8 & .4 & 1445 & 56 & 40 \\
\hline 6.0 & .2 & .7 & 1.4 & 77 & 30 & 33 \\
\hline \multicolumn{7}{|c|}{ Coto clay } \\
\hline 4.5 & .2 & 1.0 & .4 & 3010 & 41 & 56 \\
\hline 5.0 & .2 & .8 & .3 & 2465 & 32 & 52 \\
\hline 5.6 & .2 & .8 & .5 & 1970 & 34 & 50 \\
\hline 6.8 & .1 & .6 & 1.5 & 114 & 32 & 28 \\
\hline
\end{tabular}


Besides the detrimental effects of $\mathrm{Al}, \mathrm{Zn}$ toxicity could have been a factor in plant response to liming the Norfolk soil. While lime-induced $\mathrm{Zn}$ deficiency has been reported, especially on sandy soils (31), the possible toxic effects of this element at low soil $\mathrm{pH}$ has received little attention. Bennett (6) concluded that while extremely low concentrations of $\mathrm{Zn}(<1 \mathrm{p} / \mathrm{m})$ usually injure plants, $\mathrm{Zn}$ toxicity would be economi-

TABLE 7. -Composition of soybean plant material at several soil $p H$ levels

\begin{tabular}{|c|c|c|c|c|c|c|c|}
\hline Soil reaction & $\mathbf{P}$ & $\mathrm{Ca}$ & $\overline{\mathrm{Mg}}$ & $\overline{\mathrm{Mn}}$ & B & $\mathrm{Zn}$ & Mo \\
\hline$\overline{p H}$ & $\%$ & $\%$ & $\%$ & $P / m$ & $\overline{P / m}$ & $P / m$ & $\bar{P} / m$ \\
\hline \multicolumn{8}{|c|}{ Norfolk sandy loam } \\
\hline 4.5 & 0.7 & 0.5 & 0.3 & $>898$ & 55 & $>300$ & 4 \\
\hline 4.8 & .6 & .7 & .4 & $>898$ & 48 & $>300$ & 4 \\
\hline 5.6 & .5 & 1.1 & .6 & 133 & 31 & 151 & 4 \\
\hline 7.6 & .5 & 1.3 & 1.1 & 33 & 33 & 44 & 4 \\
\hline \multicolumn{8}{|c|}{ Lucedale sandy loam } \\
\hline 4.5 & .3 & 1.6 & .7 & $>898$ & 51 & $>300$ & 4 \\
\hline 4.8 & .3 & 1.8 & .4 & 297 & 43 & 241 & 5 \\
\hline 6.1 & .3 & 1.9 & 1.5 & 131 & 33 & 87 & 5 \\
\hline 7.7 & .3 & 1.7 & 1.8 & 46 & 55 & 53 & 4 \\
\hline \multicolumn{8}{|c|}{ Bladen clay } \\
\hline 4.3 & .2 & 1.0 & .7 & 77 & 34 & 244 & 4 \\
\hline 4.7 & .3 & 1.3 & .9 & 49 & 37 & 123 & 4 \\
\hline 5.4 & .3 & 1.6 & 1.2 & 11 & 43 & 99 & 4 \\
\hline 7.5 & .4 & 1.9 & 1.7 & 1 & 43 & 66 & 5 \\
\hline \multicolumn{8}{|c|}{ Catalina clay } \\
\hline 4.7 & .3 & 1.6 & .4 & $>898$ & 100 & 42 & 4 \\
\hline 4.9 & .2 & 1.7 & .5 & 412 & 103 & 36 & 4 \\
\hline 5.5 & .2 & 1.6 & .7 & 155 & 85 & 33 & 4 \\
\hline 6.0 & .2 & 1.5 & .8 & 119 & 75 & 38 & 4 \\
\hline \multicolumn{8}{|c|}{ Humatas clay } \\
\hline 4.8 & .2 & 1.6 & .5 & 150 & 103 & 45 & 3 \\
\hline 5.0 & .2 & 1.7 & .6 & 124 & 103 & 42 & 4 \\
\hline 5.6 & .2 & 1.5 & .5 & 21 & 91 & 38 & 3 \\
\hline 6.0 & .2 & 1.5 & .7 & 17 & 86 & 37 & 4 \\
\hline \multicolumn{8}{|c|}{ Coto clay } \\
\hline 4.5 & .2 & 1.4 & .5 & 646 & 103 & 45 & 4 \\
\hline 5.0 & .2 & 1.3 & .4 & 265 & 102 & 41 & 4 \\
\hline 5.6 & .2 & 1.5 & .6 & 48 & 103 & 42 & 4 \\
\hline 6.0 & .2 & 1.5 & .8 & 46 & 93 & 29 & 4 \\
\hline
\end{tabular}

cally significant only in special situations since it is rare for most soils. The bulk sample of Norfolk soil had been taken from a field on which peanuts had been grown for several years and fungicides containing $\mathrm{Zn}$ had been used. Plant material from all three test crop species grown at $\mathrm{pH}$ levels below about 5 contained very high $(>300 \mathrm{p} / \mathrm{m})$ levels of $\mathrm{Zn}$ compared to those present when the soil had been limed to $\mathrm{pH}$ values of 6 or higher ( 80 to $100 \mathrm{p} / \mathrm{m}$ ) (tables 5 through 7 ). 
Manganese content of the plant material was relatively high at very low soil $\mathrm{pH}$ values, but there was no clear evidence of either Mn toxicity in the unlimed soil or of $\mathrm{Mn}$ deficiency in the highly limed soil.

\section{Lucedale Sandy Loam}

Sudangrass and soybeans responded sharply to increasing soil $\mathrm{pH}$ in the lower range (figure 6 ) but not above about $\mathrm{pH}$ 5.8. Soil solution A1 activity was high at very low soil $\mathrm{pH}$ levels, but decreased rapidly as $\mathrm{pH}$ increased from about 4.7 (table 3). Since $\mathrm{Mn}$ level in the soil solution
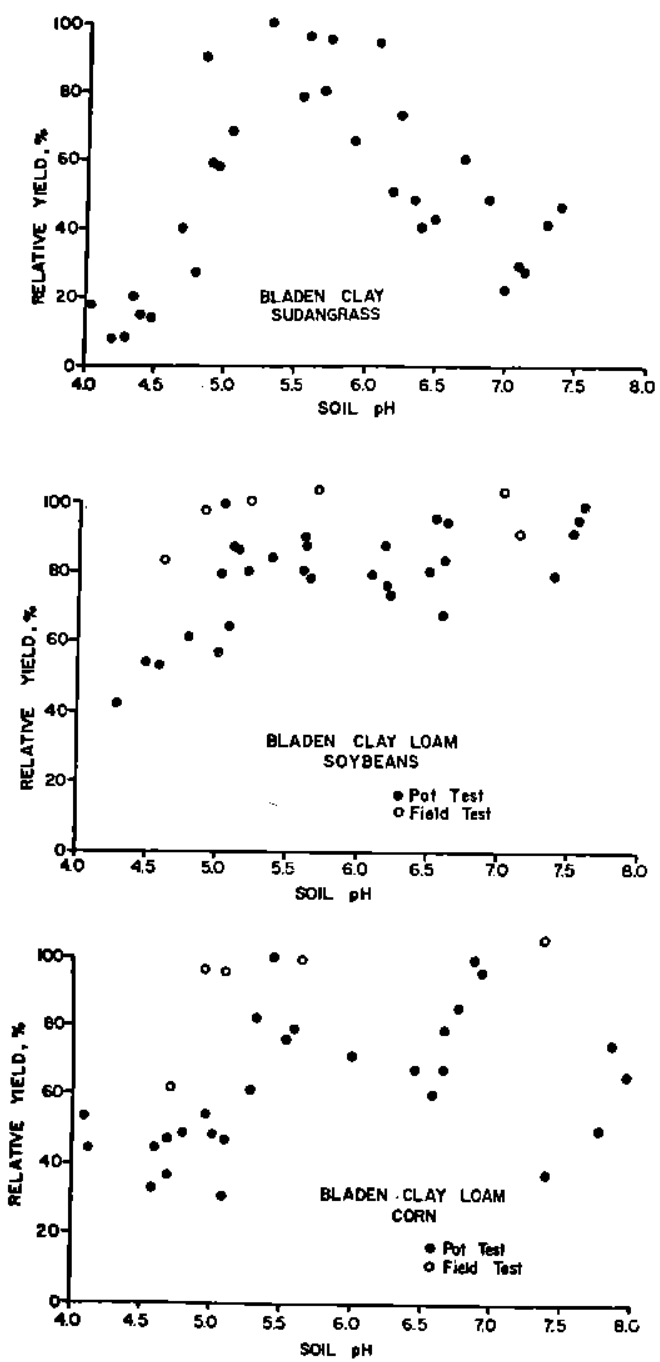

Fig. 4. - Relationship between soil pH and yield of three test crops on Bladen soil. 

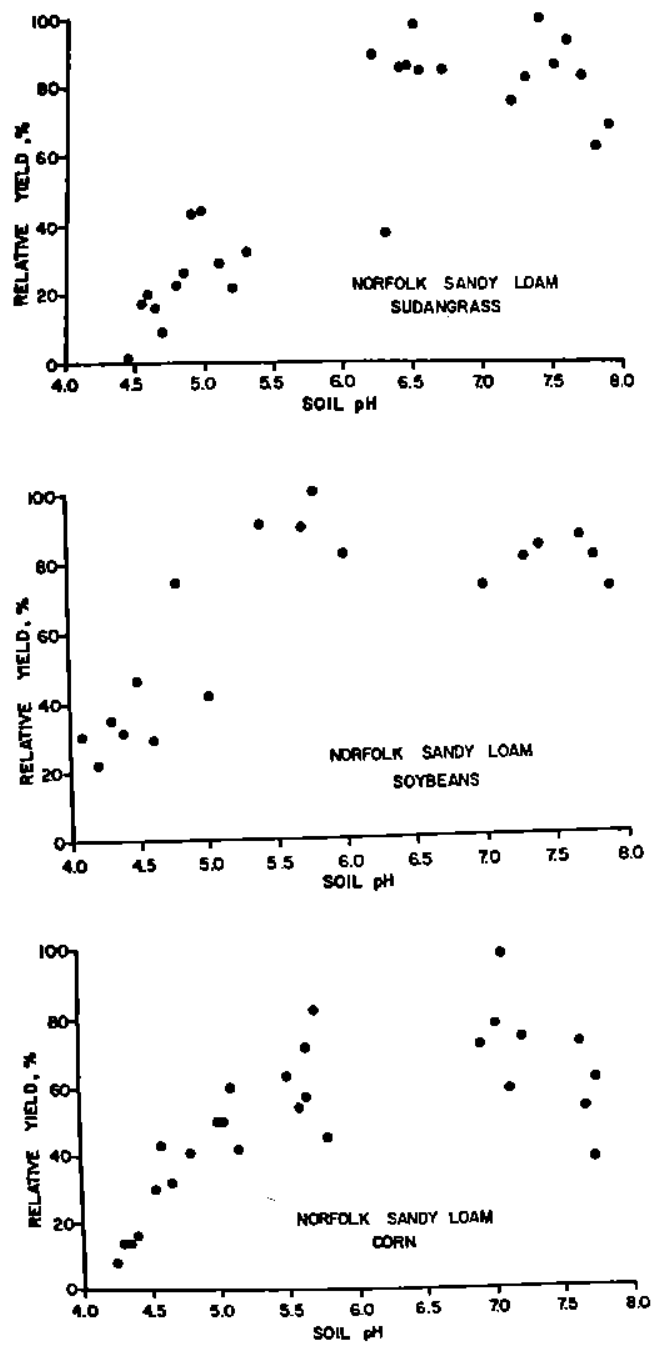

Frg. 5. - Relationship between soil pH and yield of three test crops on Norfolk soil.

was low except in the most acid treatments, and Mn content of the plant material did not appear excessive (tables 5, 7), possibly the observed response of sudangrass and soybeans to liming this soil was due to correcting $\mathrm{Al}$ toxicity.

Corn, however, had no clear response pattern. Experimental error was high, as shown by the data point scatter. Neither soil solution nor plant composition results adequately explain this behavior. Soil-solution $\mathrm{Al}$ activity was high at the lower $\mathrm{pH}$ levels, ranging up to $184 \mu \mathrm{M}$. At similar levels of activity, corn growth was severely limited in some of the other soils, e.g., Bladen. Both $\mathrm{Mn}$ and $\mathrm{Zn}$ contents of the plant 
material were unusually high $(>898 \mathrm{p} / \mathrm{m}$ and $>300 \mathrm{p} / \mathrm{m}$, respectively) when grown on Lucedale soil at $\mathrm{pH}$ levels of about 4.0 (table 6), but were within the normal range when soil $\mathrm{pH}$ was about 5.0. Thus, the lack of corn response to liming Lucedale soil could be due to either 1) response being obscured by the high experimental error, or 2) some limiting growth factor that was not dependent upon soil $\mathrm{pH}$.

\section{Humatas Clay}

Responses of the three test crops to liming Humatas soil are shown in figure 7. Sudangrass gave a tremendous yield increase, from no growth
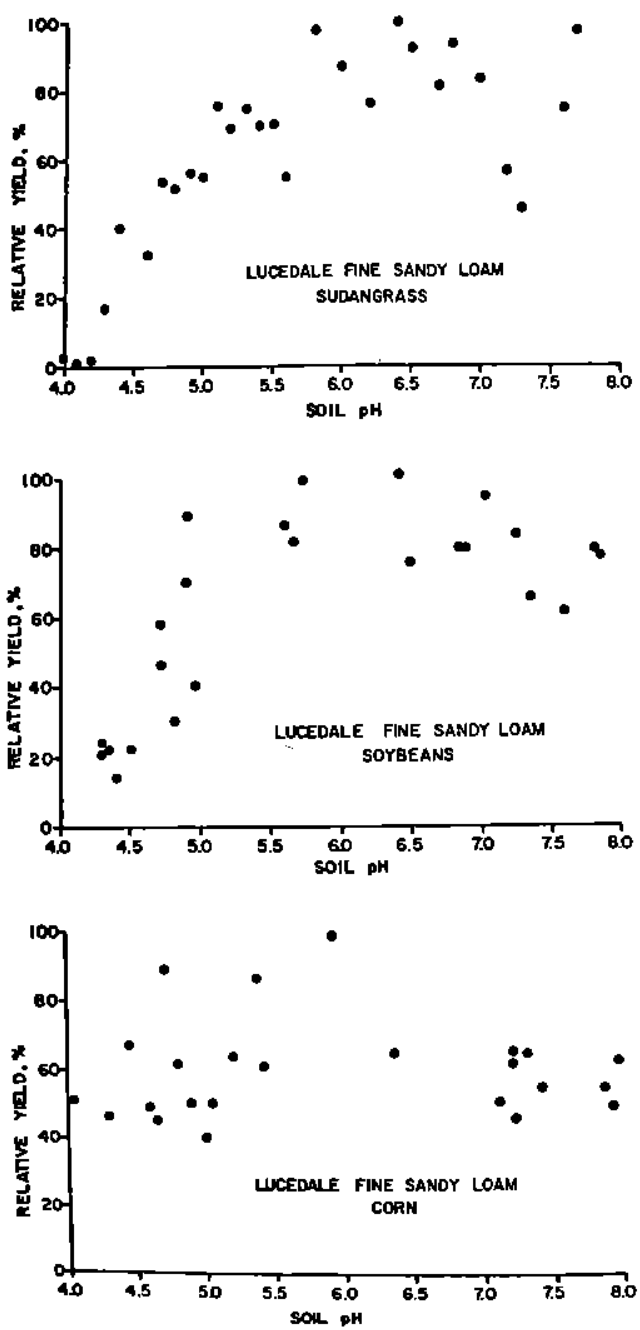

FIG. 6. -Relationship between soil pH and yield of three test crops on Lucedale soil. 

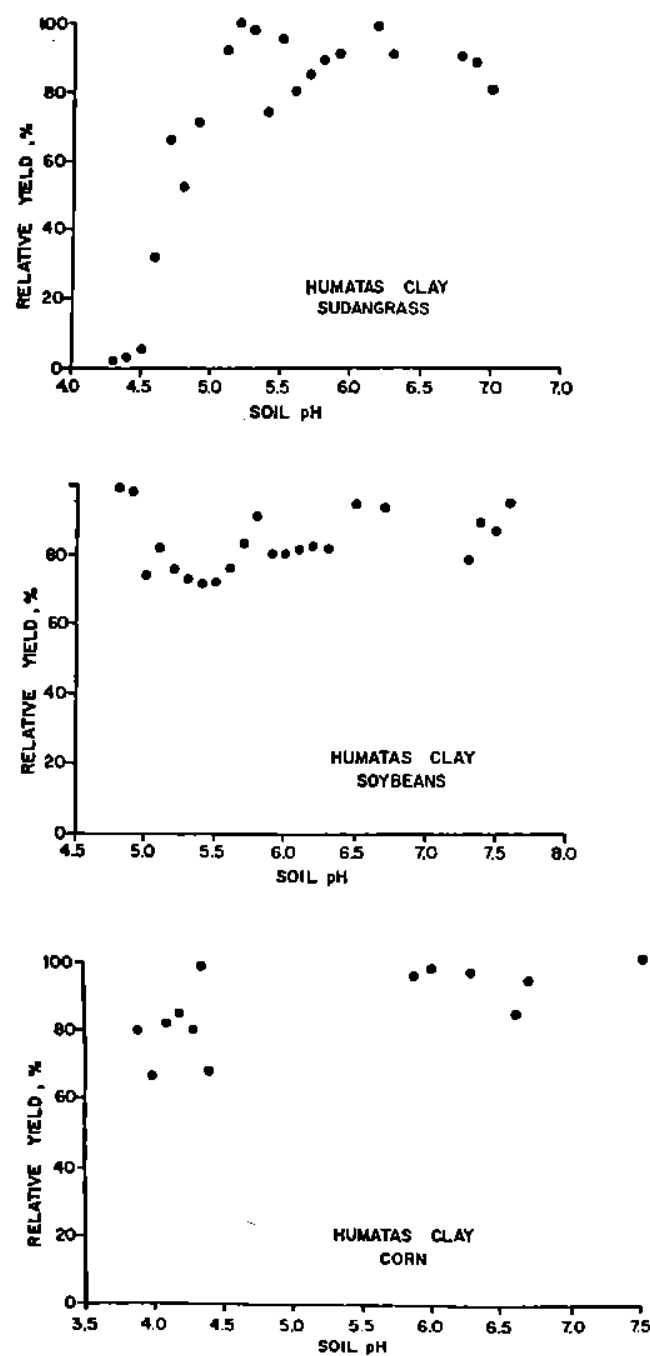

FIG. 7. - Relationship between soil $\mathrm{pH}$ and yield of three test crops on Humatas soil.

at soil $\mathrm{pH}$ of 4.4 to maximum yield at about $\mathrm{pH}$ 5.5. Corn and soybeans showed no clear response over the same $\mathrm{pH}$ range, although corn tended to respond. In this soil neither $\mathrm{Mn}$ nor $\mathrm{Zn}$ toxicities were possible limiting factors (tables 4 and 6) and Al nearly disappeared from the soil solution at pH 4.9 (table 4 and figure 1). Thus, observed yield responses are consistent with measured soil characteristics, and are attributed to neutralization of soluble $\mathrm{Al}$. 
Catalina Clay

Yield responses of the three test crops to lime application are shown in figure 8. Sudangrass and corn yields increased sharply as soil $\mathrm{pH}$ increased at the very low levels, after which there was no further effect of liming. The behavior of soybeans was more difficult to define due to the wide data point scatter.
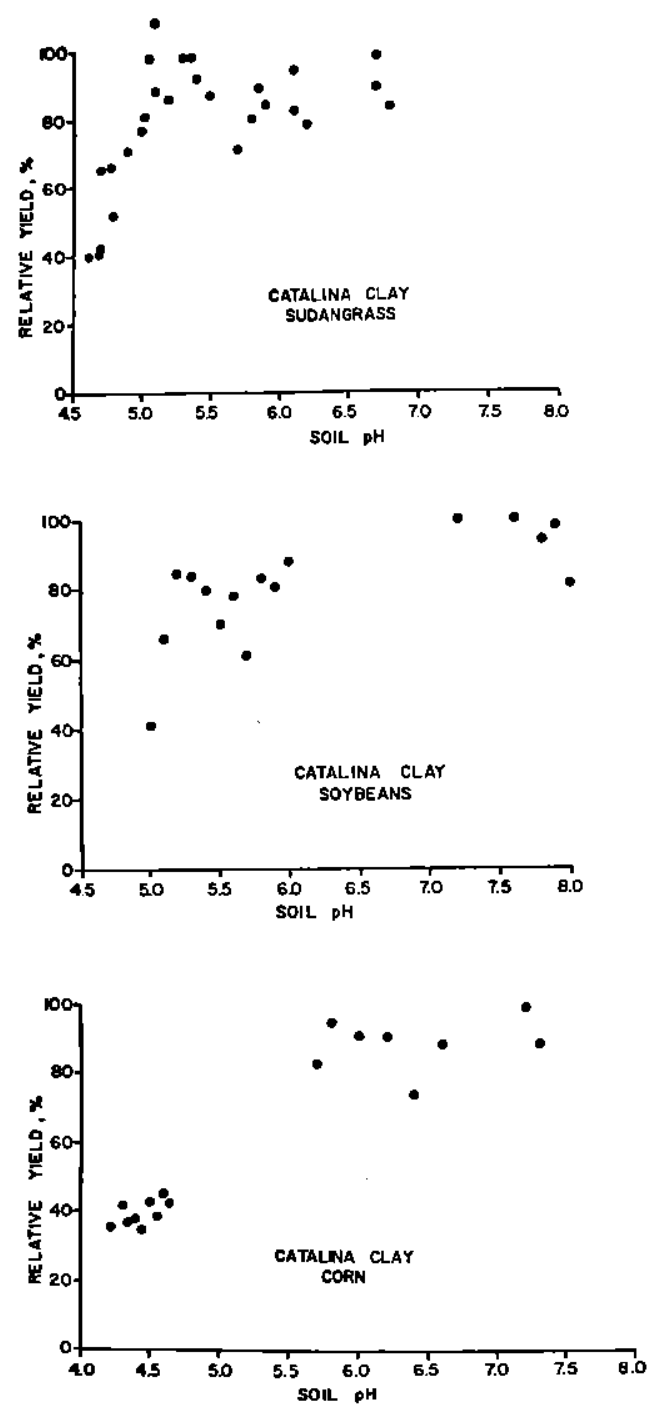

FIG. 8. - Relationship between soil $\mathrm{pH}$ and yield of three test crops on Catalina soil. 

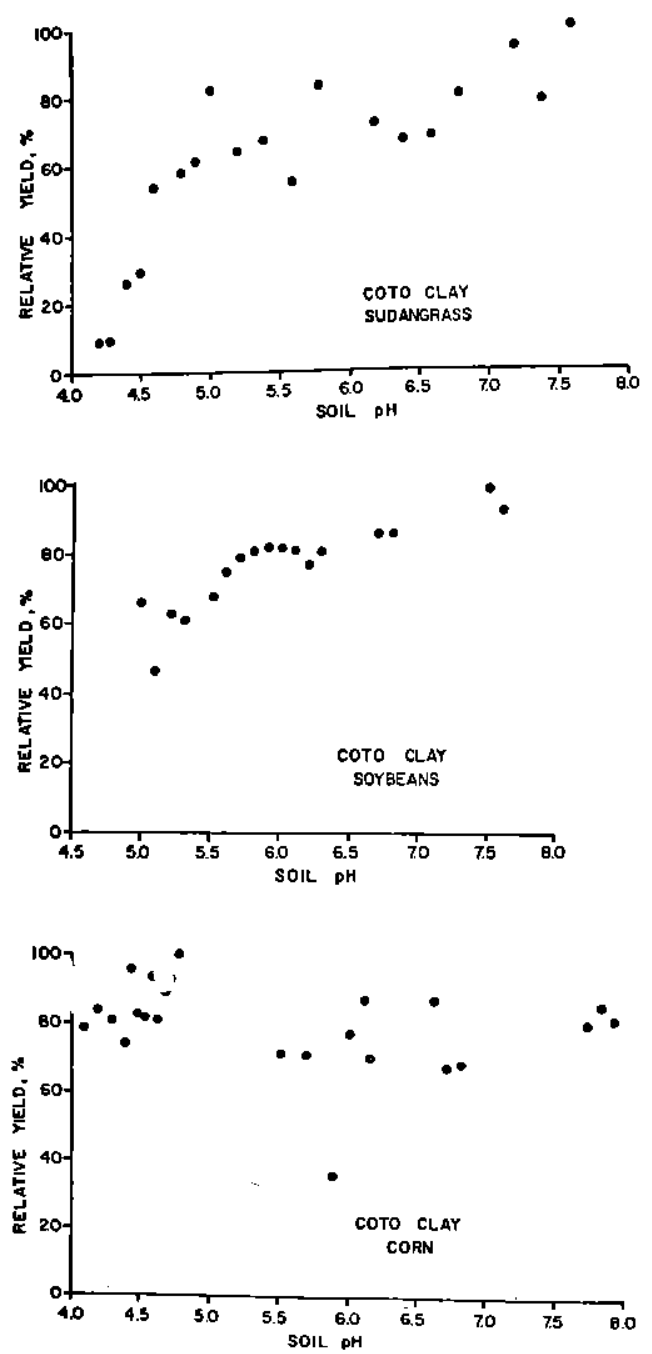

FIG. 9. - Relatienship between soil $\mathrm{pH}$ and yield of three test crops on Coto soil.

In this soil solution $\mathrm{Al}$ activity was relatively low, and $\mathrm{Mn}$ seems to have had a definite role. This agreed with plant composition results (tables 5 through 7), which show Mn content of all plant materials to be extremely high at soil pH levels of about 5.0 or lower.

Soybean yield responded to increasing soil $\mathrm{pH}$ at least through $\mathrm{pH}$ 6.0. Unfortunately, soil $\mathrm{pH}$ values of this soil had shifted when the soybean test crop was planted, and $\mathrm{pH}$ levels below 5.0 are not represented. However, the data cannot be correlated clearly with results reported by Martini et al. (18), who found that maximum soybean yield on five 
Oxisols in southern Brazil was usually reached when soils were limed to pH 5.2 to 5.7. Their results are generally consistent with those reported by Hanh (Aluminum and manganese toxicity to soybeans [Glycine max L., Merrill] M. S. thesis, Auburn University, Auburn, Alabama, 1973) for highly weathered and leached soils of the southeastern U. S., and with the optimum soil $\mathrm{pH}$ range reported by Kamprath (16) for soybeans growing on Ultisols in North Carolina. In the field experiments in southern Brazil (18), soybeans responded to liming five Oxisols where initial soil $\mathrm{pH}$ ranged from 4.4 to 5.4. It was concluded from these results and from pot studies with two of the soils that both $\mathrm{Al}$ and $\mathrm{Mn}$ toxicities were probably involved in some of the soils. Their results indicated that $1,000 \mathrm{p} / \mathrm{m} \mathrm{Mn}$ in the plant would be toxic. This approximate level was reported by Hanh, who found toxicity symptoms and depression of top growth when Mn content of leaves increased to $750 \mathrm{p} / \mathrm{m}$.

Thus, in the Catalina soil Mn toxicity apparently was the primary cause of soybean yield depression at soil $\mathrm{pH}$ values below about 6.0 . The problem of shifting soil $\mathrm{pH}$ is evident in the corn response curve of figure 8 . The gap between soil $\mathrm{pH}$ values of about 4.8 and 5.8 makes it impossible to locate more than an approximate local maximum, which appears to lie at about $\mathrm{pH}$ 5.5. Here again, soil solution $\mathrm{Al}$ level cannot adequately explain the response of corn to liming, and $\mathrm{Mn}$ must have played a dominant role. This was supported by the Mn content of corn tissue grown at $\mathrm{pH}$ levels above 5.0 (table 6) where $\mathrm{Al}$ in this soil solution would be an insignificant factor.

\section{Coto Clay}

Like the other Oxisol (Catalina), sudangrass grown on Coto soil responded to liming, soybeans responded less and the increase persisted to a higher $\mathrm{pH}$ level, while corn gave no response (figure 9).

Sudangrass yield appeared to reach a maximum at a $\mathrm{pH}$ of about 5.3 after increasing very sharply with increasing $\mathrm{pH}$ from just above 4 . Manganese content of the plant material was very high at soil $\mathrm{pH}$ values up to and slightly above 5 (table 5). Aluminum activity in the soil solution was relatively low even at soil $\mathrm{pH}$ levels where yield was depressed. It thus seems likely that $\mathrm{Mn}$ toxicity was important in sudangrass behavior on this soil, although Al toxicity probably was involved also at very low $\mathrm{pH}$ values.

Soybean yield on the Coto soil tended to increase at a relatively constant rate throughout the range tested. This response cannot be explained by $\mathrm{Mn}$ toxicity based on plant composition, and a full explanation for this response is not possible at this time.

Complete lack of response by corn to liming the Coto, even though $\mathrm{pH}$ values as low as 4.2 were measured, is also an enigma. At that value, $\mathrm{Al}$ 
activity should have been sufficiently high $(196 \mu \mathrm{M})$ to depress yield. Also, Mn content of the corn tissue, even at $\mathrm{pH} 4.5$, was high.

\section{OVERLIMING}

The results presented in figures 4 through 9 support the conclusion that overliming is not a common hazard among representative upland soils of Puerto Rico or the southeastern U. S. Only one crop, sudangrass, on only one soil, Bladen, showed a clear decline in yield as soil $\mathrm{pH}$ was increased above 6 . This is consistent with previously reported results (23).

\section{RESUMEN}

EI comportamiento de tres especies de plantas: yerba Sudán (sorgo sudanense), sojas y maíz, sembradas en suelos ácidos del sureste de los Estados Unidos y de Puerto Rico, se estudió en condiciones de invernadero. Las plantas se sembraron en tiestos. A los suelos se les administraron varios niveles de encalado para que el $\mathrm{pH}$ variara de 3.9 a 6.7 , y el contenido en aluminio entre 0 y 5.66 miliequivalentes por $100 \mathrm{~g}$. de suelo.

Se recolectaron datos de la producción de materia seca correlacionada con el pH. Este también se correlacionó con la actividad iónica del aluminio y el manganeso en la solución de los distintos suelos. De los seis suelos usados, dos (Catalina y Coto, de Puerto Rico), se clasificaron como Oxisols y los otros cuatro (Bladen, Lucedale y Norfolk, de Estados Unidos y Humatas, de Puerto Rico) como Ultisols.

Los datos relativos a los distintos suelos mostraron diferencias notables en la actividad iónica. Los Oxisols mostraron gran actividad iónica del manganeso, mientras que en el caso de los Ultisols el aluminio fue más activo. Los suelos de Puerto Rico arrojaron mayor actividad iónica, tanto del aluminio como del manganeso, al compararse con los del sureste de los Estados Unidos.

De las tres especies de plantas estudiadas, la yerba Sudán pareció ser la más sensitiva a los valores bajos de $\mathrm{pH}$ y a las altas concentraciones de aluminio. Por otro lado, las sojas y el maíz respondieron en forma parecida en algunos suelos, pero variaron en otros.

En términos generales puede decirse que se observaron tres patrones de respuesta, pero no fue posible establecer un patrón definido entre especies o entre suelos. A base de la' frecuencia en que ocurrieron, los tres patrones de respuesta fueron los siguientes: 1) aumento en la producción a medida que ascendía el $\mathrm{pH}$, lográndose el mayor aumento entre $\mathrm{pH} 5$ y 6 , seguido por una muy leve respuesta a $\mathrm{pH}$ superior a 6 ;2) ninguna respuesta a ascensos en el $\mathrm{pH}$; 3) aumento constante en la producción a medida que ascendía el $\mathrm{pH}$ hasta un máximo entre 5 y 6 , seguido por una disminución en producción a $\mathrm{pH}$ que se aproxime a 7 .

Los datos confirman la teoría de que el pH crítico para el crecimiento de las plantas es corrientemente más bajo en los suelos de Puerto Rico que en los del sureste de los Estados Unidos. También puede concluirse que la experiencia obtenida con el encalado en zonas templadas pudiera utilizarse en zonas tropicales si se toman las debidas providencias.

\section{LITERATURE CITED}

1. Abruña, F., Pearson, R. W., and Pérez-Escolar, R., Lime response of corn and beans grown on typical Oxisols and Ultisols of Puerto Rico. In Elemer Bornemisza and Alfredo Alvarado, ed., Soil Management in Tropical America pp. 261-81. North Carolina State University Press. 1975.

2. Adams, Fred, and Lund, Z. F., Effect of chemical activity of soil solution aluminum on cotton root penetration of acid subsoils. Soil Sci. 101: 193 8, 1966.

3. - and Pearson, Robert W., Crop response to lime in the southern United States and Puerto Rico, in R. W. Pearson and Fred Adams, ed, Soil acidity and liming, Agron. No. 12, pp. 161-206. Am. Soc. of Agron., Madison, Wis., 1967.

4. - - Response of cotton to lime in field experiments. Auburn Univ. Agr. Exp. Sta. Bull. 376, 1968. 
5. Armiger, W. H., Foy, C. D., Fleming, A. L., and Caldwell, B. E., Differential tolerance of soybean varieties to an acid soil high in exchangeable aluminum. Agron. J. 60: 67-70, 1968.

6. Bennett, A. C., Toxic effects of aqueous ammonia, copper, zinc, lead, boron, and manganese on root growth. p. 669-83 in E. W. Carson, ed, The plant root and its environment. University Press of Virginia, 1974.

7. Brenes, Eduardo, and Pearson, R. W., Root response of three gramineae species to soil acidity in an Oxisol and an Ultisol. Soil Sci. 116: 295-302, 1973.

8. Chenery, E. M., A preliminary study of aluminum and the tea bush. Plant Soil 6: $174-200,1955$.

9. Drosdoff, M., Soil micronutrients. p. 150-62, in Matthew Drosdoff, chairman, Soils of the humid tropics. Natl. Acad. of Sciences, Washington, D.C., 1972.

10. Evans, C. E., and Kamprath, E. J., Lime response as related to percent Al saturation, solution Al, and organic matter content. Soil Sci. Soc. Amer. Proc. 34: 893-6, 1970.

11. Foy, Charles D., Soil calcium availability. p. 601-42 in E. W. Carson, ed, The plant root and its environment. University Press of Virginia, 1974.

12. - and Brown, J. C., Toxic factors in acid soils. I. Characterization of aluminum toxicity in cotton. Soil Sci. Soc. Amer. Proc. 27: 403-7, 1963.

13 ‥ and ㄴ. Toxic factors in acid soils. Ш. Differential aluminum tolerance of plant species. Soil Sci. Soc. Amer. Proc. 28: 27-32, 1964.

14. Jackson, William A., Physiological effects of soil acidity. p. 43-124 in Robert W. Pearson and Fred Adams, ed, Soil acidity and liming. Agron. 12. Amer. Soc. of Agron., Madison, Wis., 1967.

15. Jones, L. H., and Thurmond, D. A., The determination of $\mathrm{Al}$ in soils, ash, and plant material using Eriochrome Cyanine R. Plant and Soil 9: 131-42, 1957.

16. Kamprath, E. J., Exchangeable aluminum as a criterion for liming leached mineral soils. Soil Sci. Soc. Amer. Proc. 34: 252-4, 1970.

17. - Soil acidity and liming. p. 137-41 in Matthew Drosdoff, chairman, Soils of the humid tropics. Natl. Acad. of Sciences, Washington, D.C., 1972.

18. Martini, J. A., Kochhann, R. A., Siqueira, O. J., and Borkert, C. M., Response of soybeans to liming as related to soil acidity, $\mathrm{Al}$ and $\mathrm{Mn}$ toxicities and $\mathrm{P}$ in some Oxisols of Brazil. Soil Sci. Soc. Amer. Proc. 38: 616-20, 1974.

19. Matsusaka, Yoshita, and Sherman, Donald G., Lime requirements of Hawaiian soils. Hawaii Farm Sci. 13; 5-7, 1950.

20. Oulette, G. J., and Dessureaux, L., Chemical composition of alfalfa as related to degree of tolerance to manganese and aluminum. Can. J. Plant Sci. 38: 206-14, 1958.

21. Parker, M. B., Harris, H. B., Morris, H. D., and Perkins, H. F., Manganese toxicity of soybean as related to soil fertility treatments. Agron. J. 61: 515-8, 1969.

22. Pearson, R. W., Soil environment and root development. Chapter 7 in W. H. Pierre, Don Kịkham, John Pesek, and Robert Shaw, ed, Plant environment and efficient water use. Amer. Soc. of Agron. and Soil Sci. Soc. of Amer., Madison, Wis., 1966.

23. - Soil acidity and liming in the humid tropics. Cornell Inter. Agric. Bull. 30, 1975.

24. Randall, P. J., and Vose, P. B., Effect of aluminum on uptake and translocation of phosphorus $^{32}$ by perennial ryegrass. Plant Physiol. 38: 403-9, 1963.

25. Richardson, H. L., Soil acidity and liming with tropical crops. World Crops 5: 339-40, 1951.

26. Ríos, M. A., and Pearson, R. W., The effect of some chemical environmental factors on cotton root behavior. Soil Sci. Soc. Amer. Proc. 28: 232-5, 1964.

27. Soil Survey Staff, Soil survey laboratory data and descriptions for some soils of 
Puerto Rico and the Virgin Islands. USDA Soil Cons. Serv. in cooperation with Univ. Puerto Rico Agric. Exp. Sta., Soil Surv. Investigations Rep. No. 12, 1967.

28. Spain, J. M., Frances, C. A., Howeler, R. W., Calvo, F. Differential species and varietal tolerance to soil acidity in tropical crops and pastures. In Elemer Bornemisza and Alfredo Alvarado, ed, Soil Management in Tropical America pp. 308-29. North Carolina State University Press, 1975.

29. Venema, K. C. W., Some notes on $\mathrm{pH}$, lime status, lime requirements, and liming of subtropical and tropical soils. Potash Rev. Subject 5, 17th suite, 1-13, Aug. 1961.

30. Vose, P. B., and Koontz, H. V., The uptake of strontium and calcium from soils by grasses and legumes and the possible significance in relation to SR-90 fallout. Hilgardia 29; 575-85, 1960.

31. Wear, J. I., and Hagler, T. B., Zinc status and needs of the southern region. Plant Food Rev. Vol, 9 (No. 1), 1963.

32. Zelazny, L. W., and Calhoun, F. G., Mineralogy and associated properties of tropical and temperate soils in the Western Hemisphere. Soil Crop Sci. Soc. Fla. Proc. 31: 179-89, 1971. 